Brief communication / Краткие сообщения

DOI: https://doi.org/10.21285/2227-2925-2021-11-3-497-501

\title{
Prediction of the biological activity of a compound depending on its NH-acidity
}

\author{
(c) Galina B. Nedvetskaya*, Yuliya A. Aizina ${ }^{* * * * *}$ \\ *Irkutsk State University, Irkutsk, Russian Federation \\ ** Irkutsk National Research Technical University, \\ Irkutsk, Russian Federation \\ ${ }^{\star \star \star}$ A.E. Favorsky Irkutsk Institute of Chemistry SB RAS, \\ Irkutsk, Russian Federation
}

\begin{abstract}
Acetamides are building blocks for the synthesis of compounds containing pharmacophores in their structure, manifesting a diverse range of biological activity. The drugs based on these substances possess antidiabetic effect and inhibit blood coagulation. Some of them act as chemosensitizers (i.e., cancer cell inhibitors). However, the full potential of these compounds remains to be fully accomplished. In a previous study, we synthesised acetamides with the $\mathrm{RCONHCH}\left(R^{\prime}\right) \mathrm{CCl}_{3}$ general formula (where $\mathrm{R}=\mathrm{CH}_{3}, \mathrm{CH}_{2} \mathrm{Cl}$; $R^{\prime}=\mathrm{C}_{6} \mathrm{H}_{5}, \mathrm{C}_{6} \mathrm{H}_{4} \mathrm{CH}_{3}, \mathrm{C}_{6} \mathrm{H}_{4} \mathrm{OCH}_{3}, \mathrm{C}_{6} \mathrm{H}_{4} \mathrm{OH}$ ) and studied their acid-base behaviour. The $\mathrm{NH}$-acidity of the studied acetamides is controlled by the polar effects of substituents. In this paper, the potential biological activity of the previously obtained acetamides is calculated, and the dependence of their biological potential on the $\mathrm{NH}$-acidity values is elucidated. Prediction of biological activity was carried out using the PASS software. An analysis of the types of biological activity occurring in all compounds allowed us to determine a linear dependence between the probability of biological potential and the value of dissociation constant.
\end{abstract}

Keywords: acetamides, $\mathrm{NH}$-acidity, dissociation constants, half neutralisation potential, potentiometric titration, PASS

For citation: Nedvetskaya GB, Aizina YuA. Prediction of the biological activity of a compound depending on its NH-acidity. Izvestiya Vuzov. Prikladnaya Khimiya i Biotekhnologiya = Proceedings of Universities. Applied Chemistry and Biotechnology. 2021;11(3):497-501. (In Russian) https://doi.org/10.21285/2227-2925-202111-3-497-501

УдК $542.06+57.088$

Установление зависимости потенциала биологической активности от NH-кислотности соединения

\author{
Г.Б. Недвецкая*, Ю.А. Айзина \\ * Иркутский государственный университет, г. Иркутск, Российская Федерация \\ ** Иркутский национальный исследовательский технический университет, \\ г. Иркутск, Российская Федерация \\ *** Иркутский институт химии им. А.Е. Фаворского СО РАН, \\ г. Иркутск, Российская Федерация
}

\begin{abstract}
Резюме: Ацетамиды являются строительным материалом для синтеза соединений, содержащих в своей структуре фрармакоффорные группы, которые проявляют различную биологическую активность. Созданные на их основе препараты обладают противодиабетическим действием, являются ингибиторами фрактора свертывания крови, некоторые действуют как хемо-сенсибилизаторы (т.е. блокаторы раковых клеток). Однако в полной мере возможности этих соединений не раскрыты. Ранее нами были синтезированы ацетамиды с общей формулой $R C O N H C H\left(R^{\prime}\right) C C l_{3}$ (2де $R=C_{3}, C_{2} \mathrm{Cl}_{;} R^{\prime}=C_{6} H_{5}$, $\left.\mathrm{C}_{6} \mathrm{H}_{4} \mathrm{CH}_{3}, \mathrm{C}_{6} \mathrm{H}_{4} \mathrm{OCH}_{3}, \mathrm{C}_{6} \mathrm{H}_{4} \mathrm{OH}\right)$ и изучено их кислотно-основное поведение. Показано, что $\mathrm{NH}$-кислотность исследованных ацетамидов контролируется полярным эфффектом заместителей. Целью настоящей работы являлся расчет потенциальной биологической активности полученных ранее ацетамидов и установление зависимости биологического потенциала от величины NH-кислотности этих соединений. Прогноз биологической активности осуществлен с использованием компьютерной программы PASS. В результате отбора активностей, встречающихся во всех соединениях, установлена линейная зависимость вероятности наличия биологической активности от величины константы диссоциации соединения.
\end{abstract}

Ключевые слова: ацетамиды, NH-кислотность, константы диссоциации, потенциал полунейтрализации, потенциометрическое титрование, PASS 
Для цитирования: Недвецкая Г.Б., Айзина Ю.А. Установление зависимости потенциала биологиче-

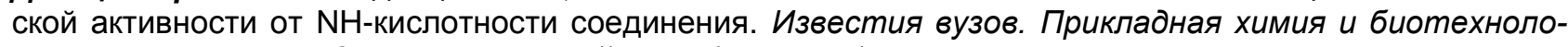
гия. 2021. Т. 11. N 3. С. 497-501. https://doi.org/10.21285/2227-2925-2021-11-3-497-501

\section{INTRODUCTION}

Acetamids are one of the most important compound classes from the chemical point of view. They are a building material for creating compounds which contains several pharmacophore groups in their structure. Such compounds, of course, have a biological activity. Acetamids are a part of drugs with diabetic inhibitor ${ }^{1}$, coagulation factor inhibitor [1] and some of them are blockers for the cancer cells [2, 3]. Acetamids exhibit anticonvulsant [4], antiviral [5], analgesic [6] and insecticides [7] activities.

The possibilities of these compounds are not fully understood. Acetamids with general structure $\mathrm{RCONHCH}\left(\mathrm{R}^{\prime}\right) \mathrm{CCl}_{3}\left(\mathrm{R}=\mathrm{CH}_{3}, \mathrm{CH}_{2} \mathrm{Cl} ; \mathrm{R}^{\prime}=\mathrm{C}_{6} \mathrm{H}_{5}\right.$, $\mathrm{C}_{6} \mathrm{H}_{4} \mathrm{CH}_{3}, \mathrm{C}_{6} \mathrm{H}_{4} \mathrm{OCH}_{3}, \mathrm{C}_{6} \mathrm{H}_{4} \mathrm{OH}$ ) had been studied by us before. The polar effect of substituents controls $\mathrm{NH}$-acidic of the studied compounds [8].

The main idea of this project is to establish the $\mathrm{NH}$ acidic potential dependence and biological activity. Our work consists of two stages. We use the PASS online program for the previously obtained acetameds [9] and compare with $\mathrm{NH}$ value biological potential [8].

\section{EXPERIMENTAL PART}

We used the PASS (Prediction of Activity Spectra for Substances) on-line program criteria biologi- cal activity assessment. It is a useful tool to make a quick forecasting of diverse biological activity $[10,11]$. PASS is a software product designed as a tool for evaluating the general biological potential of an organic drug-like molecule. This program predicts a lot of types of biological activities based on the organic compounds structure [12, 13].

\section{RESULTS AND DISCUSSION}

The dissociation constant acetamids $\mathrm{pK}_{\mathrm{A}}(\mathrm{NH}-$ acidity) has been determined the potentiometric method on "Expert-001» [14-18] as well as biological activity factors $(\mathrm{Pa})$ substances. Table contains the results of the biological activity evaluation acetamids.

Table depicts dissociation constant acetamids due to different (R) substituents of substances. However, substituents equidistant from the $-\mathrm{CONH}-$ active center and this fact affects the constant compounds I-IV dissociation. The acidity span $\left(\mathrm{pK}_{\mathrm{A}}\right)$ of these compounds varies slightly (from 12 to 14 units). The main contribution to the $-\mathrm{NH}$ group proton mobility and the acidity of these compounds made by the presence of chlorine near the active center. Therefore, these compounds acidity increases to 12 units in comparison with the previously described compounds [19]. In compound $\mathbf{V}$, there

Relationship between biological activity ( $\mathrm{Pa})$ and $\mathrm{NH}$-acidity (pKA) of acetamides

Взаимосвязь биологической активности $(\mathrm{Pa})$ и $\mathrm{NH}$-кислотности $\left(\mathrm{pK}_{\mathrm{A}}\right)$ ацетамидов

\begin{tabular}{|c|c|c|c|c|c|}
\hline \multirow[b]{2}{*}{$\begin{array}{l}\text { The forms } \\
\text { of biological activities }\end{array}$} & \multicolumn{5}{|c|}{$\mathrm{Pa}$} \\
\hline & $\begin{array}{c}\mathrm{I} \\
\boldsymbol{p} \boldsymbol{K}_{\boldsymbol{A}}(12.03)\end{array}$ & $\boldsymbol{p} \boldsymbol{K}_{\boldsymbol{A}}(12.33)$ & $\mathbf{p K}_{\boldsymbol{A}}(12.68)$ & $\mathbf{p K _ { \boldsymbol { A } } ( 1 2 . 8 6 )}$ & $\mathbf{p K}_{\boldsymbol{A}}(14.06)$ \\
\hline 1. Phobic disorders & 0.767 & 0.660 & 0.598 & 0.573 & 0.772 \\
\hline 2. Chloride peroxidase & 0.585 & 0525 & 0.398 & 0.394 & 0553 \\
\hline $\begin{array}{l}\text { inhibitor } \\
\text { 3. Fusarinine-C }\end{array}$ & 0.000 & $0.0<0$ & & 0.054 & \\
\hline ornithinesterase inhibitor & 0.580 & 0.487 & 0.475 & 0.473 & 0.634 \\
\hline $\begin{array}{l}\text { 4. Complement factor } \\
\text { D inhibitor }\end{array}$ & 0.577 & 0.483 & 0.474 & 0.415 & 0.600 \\
\hline $\begin{array}{l}\text { 5. Enteropepti-dase } \\
\text { inhibitor }\end{array}$ & 0.558 & 0.462 & 0.459 & 0.428 & 0.391 \\
\hline $\begin{array}{l}\text { 6. Hematopoietic } \\
\text { inhibitor }\end{array}$ & 0.541 & 0.486 & 0.445 & 0.395 & 0.512 \\
\hline 7. Angiogenesis inhibitor & 0.426 & 0.393 & 0.386 & 0.327 & - \\
\hline $\begin{array}{l}\text { 8. Transglutaminase } \\
2 \text { inhibitor }\end{array}$ & 0.343 & 0.303 & 0.291 & 0.276 & - \\
\hline
\end{tabular}

${ }^{1}$ Машковский М.Д. Лекарственные средства: пособие для врачей. 16-е изд., перераб., испр. и доп. М.: Новая волна. 2012. 1216 с. 
is a donor methyl group near the active center that reduces proton mobility with nitrogen, so the acid strength of this compound is significantly reduced $\left(\mathrm{pK}_{\mathrm{A}}=14.08\right)$.

We chose only those activities which are found in all compounds and analyzed them.

Table presents linear relation biological activity and $\mathrm{NH}$-acidic for the first acetamides. The probability biological activity increases with growing coefficient acidity of the compounds. In case of the (V) last compound the probability of the 1-4 species biological activities dramatically increases. Meanwhile, 7 and 8 species show zero biological activity.
The $\mathrm{NH}$-acidity compound decrease can be explained by the inverse relationship. According to the list of references [12], there are nootropic properties which contain chlorine compound. There have not been any nootropic activities found despite the presence of three or four chlorine atoms in research compounds.

\section{CONCLUSION}

Acetamids I-V biological activity theoretical prediction was made. $\mathrm{NH}$ value biological potential line dependence on compound dissociation constant value has been set.

\section{REFERENCE}

1. Wilkinson $B L$, Innocenti $A$, Vullo $C$, Supuran CT, Poulsen S-A. Inhibition of carbonic anhydrases with glycosyltriazole benzene sulfonamides. Journal of Medicinal Chemistry. 2008;51(6):1945-1953. https://doi.org/10.1021/jm701426t

2. Moeker J, Mahon BP, Bornaghi LF, Vullo D, Supuran CT, McKenna R, et al. Structural insights into carbonic anhydrase IX isoform specificity of carbohydrate-based sulfamates. Journal of Medicinal Chemistry. 2014;57(20):8635-8645. https://doi. org/10.1021/jm5012935

3. Lichtenstein DR, Wolfe MM. COX-2 selective NSAIDs: new and improved? Journal of the American Medical Association. 2000;284(10):1297-1299. https://doi.org/10.1001/jama.284.10.1297

4. Bunyatyan ND, Kovalenko SN, Severina HI, Mokhamad EKW, Zalevskyi SV, Shtrygol' SY, et al. Synthesis and anticonvulsant activity of new 2-(4-oxo2-thioxo-1,4-dihydro-3(2h)-quinazolinyl)acetamides.

Pharmaceutical Chemistry Journal. 2020;54(1). 6 p. https://doi.org/10.1007/s11094-020-02147-5

5. Shadyro OI, Sorokin VL, Ksendzova GA, Savinova OV, Samovich SN, Boreko El. Comparative evaluation of the antiherpes activity of compounds with different mechanisms of action. Pharmaceutical Chemistry Journal. 2019;53(7):646-649. https://doi.org/10.1007/s11094-019-02055-3

6. Mikhailovskii AG, Pogorelova ES, Pershina NN, Makhmudov RR, Novikova VV. Synthesis, analgetical, antihypoxic and antimicrobial activity for (z)-2-(2-arylhydrazono)-2-(3,3-dimethyl-3,4-dihydroisoquinoline-1-yl)acetamides. Khimiko-farmatsevticheskii zhurnal. 2019;53(11):25-29. (In Russian) https://doi.org/10.30906/0023-1134-2019-53-11-25-29

7. Kostina M.N. Food scent as the safety method against flies in the buildings. Dezinfektsionnoe Delo = Disinfection Affairs. 2015;94(4):52-60. (In Russian)

8. Plotnikova AS, Nedvetskaya GB, Aizina YuA. $\mathrm{NH}$-acidity of substituted trichlorethyl acetamides in dimethyl sulfoxide. Izvestiya Vuzov. Prikladnaya Khimiya $i$ Biotekhnologiya = Proceedings of Universities. Applied Chemistry and Biotechnology. 2018;9(1):36-43. (In Russian) https://doi.org/10.212 85/2227- 2925-2019-9-1-36-43
9. Aizina JA, Rozentsveig IB, Levkovskaya GG. A novel synthesis of chloroacetamide derivatives via $\mathrm{C}$-amidoalkylation of aromatics by 2-chloro- $\mathrm{N}-(2,2,2-$ trichloro-1-hydroxyethyl)acetamide. Arkivoc Arkat USA. 2011;8:192-199. https://doi.org/10.3998/ark.55 50190.0012 .815

10. Sergeev PV, Shimanovskii NL, Petrov VI. Receptors of physiologically active substances. Moscow; Volgograd: Sem' vetrov; 1999. 640 p. (In Russian)

11. Durnev AD, Seredenin SB. Mutagens. Screening and famacological prevention of exposures. Moscow: Meditsina; 1998. 328 p. (In Russian)

12. Aizina YuA. Use of modern information technologies for revealing biological potency of organic compounds. Vestnik Irkutskogo gosudarstvennogo tekhnicheskogo universiteta = Proceedings of Irkutsk State Technical University. 2012;4:145-149. (In Russian)

13. Aizina YuA, Nikitin AYa, Levkovskaya GG. PASS method calculated and experimental assessment of biological activity of sulfonamide polychlorinated ethylated arenes and hetarenes. Vestnik Irkutskogo gosudarstvennogo tehnicheskogo universiteta $=$ Proceedings of Irkutsk State Technical University. 2014;12:188-191. (In Russian)

14. Bykova LN. Semi-neutralization potential as a chemical-analytical characteristic of electrolytes in potentiometric titration. Zhurnal analiticheskoi khimii = Journal of Analytical Chemistry (USSR). 1969;24

(12):1781 - 1789. (In Russian)

15. Kreshkov AP, Aldarova NSh, Tanganov BB. Chemical-analytical behavior of sulfur-containing aliphatic dicarboxylic acids in non-aqueous solvents. Zhurnal analiticheskoi khimii = Journal of Analytical Chemistry (USSR). 1970;25(2):362-368. (In Russian)

16. Fialkov YuYa, Zhitomirskii AN, Tarasenko YuA. Physical chemistry of non-aqueous solutions. Leningrad: Khimiya; 1973. 376 p. (In Russian)

17. Fialkov YuYa. Not only in the water. Leningrad: Khimiya; 1989. 88 p. (In Russian)

18. Krestov GA, Novoselov NP, Perelygin IS, Kolker AM, Safonova LP, Ovchinnikova VD et al. Ionic Solvation. Moscow: Nauka; 1987. 320 p. (In Russian) 
Nedvetskaya G.B., Aizina Yu.A. Prediction of the biological activity of a compound depending ... Недвецкая Г.Б., Айзина Ю.А. Установление зависимости потенциала биологической ...

19. Kloos OV, Nedvedskaya GB, Aizina YA, Rozentsveig IB. Sulfonamides and their acidic properties in dimethylsulfoxide. Izvestiya Vuzov. Prikladnaya Khimiya $i$ Biotekhnologiya $=$ Proceedings of
Universities. Applied Chemistry and Biotechnology. 2016;6(2):23-29. (In Russian) https://doi.org/10.212 85/2227- 2925-2016-6-2-23-29

\section{СПИСОК ЛИТЕРАТУРЫ}

1. Wilkinson B.L., Innocenti A., Vullo C., Supuran C.T., Poulsen S.-A. Inhibition of carbonic anhydrases with glycosyltriazole benzene sulfonamides // Journal of Medicinal Chemistry. 2008. Vol. 51. Issue 6. P. 1945-1953. https://doi.org/10.1021/jm701426t

2. Moeker J., Mahon B.P., Bornaghi L.F., Vullo D., Supuran C.T., McKenna R., et al. Structural insights into carbonic anhydrase IX isoform specificity of carbohydrate-based sulfamates // Journal of Medicinal Chemistry. 2014. Vol. 57. Issue 20. P. 86358645. https://doi.org/10.1021/jm5012935

3. Lichtenstein D.R., Wolfe M.M. COX-2 selective NSAIDs: new and improved? // Journal of the American Medical Association. 2000. Vol. 284. Issue 10. P. 1297-1299. https://doi.org/10.1001/jama. 284.10.1297

4. Bunyatyan N.D., Kovalenko S.N., Severina H.I., Mokhamad E.K.W., Zalevskyi S.V., Shtrygol' S.Y., et al. Synthesis and anticonvulsant activity of new 2-(4-oxo-2-thioxo-1,4-dihydro-3(2h)-quinazolinyl)acetamides // Pharmaceutical Chemistry Journal. 2020. Vol. 54. Issue 1. 6 p. https://doi.org/10.10 07/s11094-020-02147-5

5. Shadyro O.I., Sorokin V.L., Ksendzova G.A., Savinova O.V., Samovich S.N., Boreko E.I. Comparative evaluation of the antiherpes activity of compounds with different mechanisms of action // Pharmaceutical Chemistry Journal. 2019. Vol. 53. Issue 7. P. 646-649. https://doi.org/10.1007/s1109 4-019-02055-3

6. Михайловский А.Г., Погорелова Е.С., Першина Н.Н., Махмудов Р.Р., Новикова В.В. Синтез, анальгическая, антигипоксическая и противомикробная активность (2)-2-(2-арилгидразона)-2-(3,3диметил-3,4-дигидроизохинолин-1-ил)-ацетамидов // Химико-фармацевтический журнал. 2019. Т. 53. N 11. C. 25-29. https://doi.org/10.30906/0023-11342019-53-11-25-29

7. Костина М.Н. Пищевая приманка как наиболее безопасный метод борьбы с мухами в помещении. // Дезинфекционное дело. 2015. Т. 94. N 4. C. $52-60$.

8. Плотникова А.С., Недведская Г.Б., Айзина Ю.А. NH-кислотность замещенных трихлорэтиламидов в среде диметилсульфоксида // Известия вузов. Прикладная химия и биотехнология. 2019. T. 9. N 1. C. 36-43. https://doi.org/10.21285/ 2227- 2925-2019-9-1-36-43

\section{INFORMATION ABOUT THE AUTHORS}

\section{Galina B. Nedvetskaya,}

Cand. Sci. (Chemistry), Associate Professor, Irkutsk State University,
9. Aizina J.A., Rozentsveig I.B., Levkovskaya G.G. A novel synthesis of chloroacetamide derivatives via $\mathrm{C}$-amidoalkylation of aromatics by 2-chloro$\mathrm{N}$-(2,2,2-trichloro-1-hydroxyethyl)acetamide // Arkivoc. Arkat USA. 2011. Vol. 8. P. 192-199. https:// doi.org/10.3998/ark.5550190.0012.815

10. Сергеев П.В. Шимановский Н.Л., Петров В.И. Рецепторы физииологически активных веществ: монография. 2-е изд., перераб. и доп. М.; Волгоград: Семь ветров, 1999. 640 с.

11. Дурнев А.Д. Середенин С.Б. Мутагены. Скрининг и фомакологическая профилактика воздействий. М.: Медицина, 1998. 328 с.

12. Айзина Ю.А. Использование современных информационных технологий для выявления биологической активности органических соединений // Вестник ИрГТУ. 2012. N 4 (63). С. 145-149.

13. Айзина Ю.А., Никитин А.Я., Левковская Г.Г. Расчетная методом PASS и экспериментальная оценка биологической активности сульфонамидополихлор-этилированных аренов и гетаренов // Вестник ИрГТУ. 2014. N 12 (95). С. 188-191.

14. Быкова Л.Н. Потенциал полунейтрализации как химико-аналитическая характеристика электролитов при потенциометрическом титровании // Журнал аналитической химии. 1969. Т. 24. N 12. C. 1781-1789.

15. Крешков А.П., Алдарова Н.Ш., Танганов Б.Б. Химико-аналитическое поведение серосодержащих алифатических дикарбоновых кислот в среде неводных растворителей // Журнал аналитической химии. 1970. Т. 25. N 2. С. 362-368.

16. Фиалков Ю.Я., Житомирский А.Н., Тарасенко Ю.А. Физическая химия неводных растворов. Л.: Химия, 1973. 376 с.

17. Фиалков Ю.Я. Не только в воде. 2-е изд., перераб. и доп. Л: Химия, 1989. 88 с.

18. Крестов Г.А., Новоселов Н.П., Перелыгин И.С., Колкер А.М., Сафонова Л.П., Овчинникова В.Д. [и др.]. Ионная сольватация. М.: Наука, 1987. $320 \mathrm{C}$.

19. Клоос О.В., Недведская Г.Б., Айзина Ю.А., Розенцвейг И.Б. Сульфонамиды и их кислотные свойства в диметилсульфррксиде // Известия вузов. Прикладная химия и биотехнология. 2016. T. 6. N 2. C. 23-29. https://doi.org/10.21285/ 2227- 2925-2016-6-2-23-29

\section{СВЕДЕНИЯ ОБ АВТОРАХ}

\section{Недвецкая Галина Борисовна,}

к.х.н., доцент,

Иркутский государственный университет, 
Nedvetskaya G.B., Aizina Yu.A. Prediction of the biological activity of a compound depending ...

Недвецкая Г.Б., Айзина Ю.А. Установление зависимости потенциала биологической ...

1, Karl Marx St., Irkutsk, 664003,

Russian Federation,

e-mail: galinanedvetskaya@gmail.com

\section{Yuliya A. Aizina,}

Cand. Sci. (Chemistry), Associate Professor,

National Research Irkutsk State Technical

University,

83, Lermontov St., Irkutsk, 664074,

Russian Federation,

e-mail: aizina@ex.estu.edu;

Reseacher,

A.E. Favorsky Irkutsk Institute of Chemistry

SB RAS,

1, Favorsky St., Irkutsk, 664033,

Russian Federation,

凶e-mail: aizina_yulia@irioch.irk.ru

\section{Contribution of the authors}

The authors contributed equally to this article.

\section{Conflict interests}

The authors declare no conflict of interests regarding the publication of this article.

The final manuscript has been read and approved by all the co-authors.

The article was submitted 13.03.2021. Approved after reviewing 29.05.2021. Accepted for publication 30.08.2021.
664033, г. Иркутск, ул. К. Маркса, 1, Российская Федерация,

e-mail: galinanedvetskaya@gmail.com

\author{
Айзина Юлия Александровна, \\ к.Х.Н., доцент, \\ Иркутский национальный исследовательский \\ технический университет, \\ 664074, г. Иркутск, ул. Лермонтова, 83, \\ Российская Федерация, \\ e-mail: aizina@ex.istu.edu; \\ научный сотрудник, \\ Иркутский институт химии им. А.Е. Фаворского \\ СO РAH, \\ 664033, г. Иркутск, ул. Фаворского, 1 , \\ Российская Федерация, \\ $凶$ e-mail: aizina_yulia@irioch.irk.ru
}

\section{Заявленный вклад авторов}

Все авторы сделали эквивалентный вклад в подготовку публикации.

\section{Конфликт интересов}

Авторы заявляют об отсутствии конфрликта интересов.

Все авторы прочитали и одобрили окончательный вариант рукописи.

Поступила в редакцию 13.03.2021.

Одобрена после рещензирования 29.05.2021.

Принята к публикации 30.08.2021. 